\title{
Sistem Pendukung Keputusan Dalam Pemilihan Belanja Online Marketplace Menggunakan Analytic Network Process (ANP)
}

\author{
Asri Ayu Larasati ${ }^{1}$, Anastasia Siwi Fatma Utami ${ }^{*}$, Feri Prasetyo ${ }^{3}$ \\ 1Sistem Informasi; STMIK Nusa Mandiri Jakarta www.nusamandiri.ac.id \\ email:asriayul2507@nusamandiri.ac.id \\ ${ }^{2}$ Sistem Informasi Akutansi; Universitas Bina Sarana Informatika \\ www.bsi.ac.id; email: anastasia.asf@bsi.ac.id \\ ${ }^{3}$ Sistem Informasi; Universitas Bina Sarana Informatika \\ www.bsi.ac.id; email: feri.fpo@bsi.ac.id \\ *Korespondensi:e-mail: anastasia.asf@bsi.ac.id
}

Diterima: 13 Mei 2020; Review:17 Mei 2020; Disetujui: 20 Mei 2020;

Cara sitasi: Larasati AA, Utami ASF, Prasetyo F. 2020. Sistem Pendukung Keputusan Dalam Pemilihan Belanja Online Marketplace Menggunakan Analytic Network Process (ANP). Informatics for Educators and Professionals. Vol.4 (2): 133-142

\begin{abstract}
Abstrak: Penilaian untuk menentukan Marketplace selama ini dilakukan secara manual dan tentunya penilaian tersebut masih bisa dipengaruhi dengan faktor yang lain, maka dari itu penelitian ini dibuat untuk membantu menentukan Marketplace yang terbaik dengan cara meminta pendapat dan penilaian dari masyarakat umum pengguna Marketplace, setelah nilai tersebut didapat akan diinput kedalam system dan setelah semua nilai diinputkan akan langsung diketahui marketplace mana yang menjadi pilihan masyarakat dalam penelitian ini ada 5 (lima) alternative yang ditentukan oleh peneliti dan ada 3 kategori yang peneliti tetapan sebagai acuan yaitu: Harga, Minat, dan Promo dengan menggunakan metode hitung ANP (Analytic Network Process) dan perhitungannya dengan bantuan software Microsoft Excel dan hasil analisis kriteria terpilih pada penelitian ini didapatkan. Kriteria harga mendapatkan bobot sebesar $(0,23)$, Kriteria promo mendapatkan bobot sebesar $(0,10)$, sedangkan kriteria minat mendapatkan bobot sebesar $(0,67)$ dari hasil perhitungan pembobotan diatas yang memiliki pembobotan terbesar dari pemilihan masyarakat yaitu kriteria minat dengan hasi $(0,67)$. Sedangkan untuk pembobotan alternatif Bukalapak memiliki nilai tertinggi dengan hasil (1.00), dengan urutan kedua Shopee, Lazada, Tokopedia, dan yang terakhir adalah Blibli.com. dari hasil berikut diharapkan dapat membantu masyarakat untuk bahan pertimbangan dalam memilih aplikasi belanja marketplace.
\end{abstract}

Kata kunci: ANP(Analytic Network Process), Kriteria, Marketplace.

\begin{abstract}
The assessment to determine Marketplace so far has been done manually and of course the assessment can still be influenced by other factors, therefore this research was made to help determine the best Marketplace by asking for opinions and ratings from the general public Marketplace users, after the value is obtained will inputted into the system and after all inputted values will be immediately known which marketplace is the choice of the community in this study there are 5 (five) alternatives determined by the researcher and there are 3 categories that researchers set as references, namely: Price, Interest, and Promos using the method calculate ANP (ANALYTIC NETWORK PROCESS) and the calculation with the help of Microsoft Excel software and the results of analysis of selected criteria in this study was obtained. Price criteria get a weighting of (0.23), promo criteria get a weighting of (0.10), while the interest criteria get a weighting of (0.67) from the results of weighting calculation above which has the largest weighting of the community selection, namely the criteria of interest with the result (0.67). Whereas for alternative weighting Bukalapak has the highest score with results (1.00), in the second place Shopee, Lazada, Tokopedia, and the last is Blibli.com. the following results are expected to help the community for consideration in choosing a marketplace shopping application.
\end{abstract}


Keywords: ANP (Analytic Network Process), Criteria, Marketplace.

\section{Pendahuluan}

Dengan meningkatnya kemajuan teknologi, membuat gaya hidup di dalam masyarakat semakin serba instan dikarenakan mayoritas masyarakat memiliki tingkat mobilitas tinggi dalam kegiatan sehari-harinya. Sehingga masyarakat seringkali mencari sesuatu yang praktis dalam memenuhi kebutuhan sehari-hari. Berbagai kegiatan dan kativitas beralih ke hal tersebut, menggunakan teknologi untuk mempermudah kegiatan sehari hari, sehingga bisa lebih evektif dan evisien, Seperti halnya di dalam dunia penjualan yang sebelumnya masih menggunakan cara konsumen mendatangi toko langsung untuk membeli suatu barang sehingga bagi yang tidak melikiki waktu banyak mereka tidak dapat berkunjung lansung ke toko tersebut. Terutama konsumen yang mobilisasinya tinggi.

Hal ini pun di manfaatkan oleh beberapa perusahaan teknologi informasi dalam menciptakan suatu inofasi tentang media penjualan online yang sering kita sebut dengan $\mathrm{E}$ commerce dan Marketplace. Dengan adanya migrasi system ini kini semua menjadi lebih praktis, Jika pada jaman dulu proses pembelian masih menggunakan cara pelanggan datang ke toko langsung maka berbeda dengan saat ini yang konsumen bisa melakukan transaksi dimana saja dan kapan saja tanpa harus datang ke toko nya langsung untuk membeli suatu barang yang di inginkan [1].

Menurut Angga Kurnia Putra dalam [2] mengemukakan bahwa Marketplace merupakan media online berbasis internet (web-based) tempat melakukan kegiatan bisnis dan transaksi antara pembeli dan penjual. Pembeli dapat mencari supplier sebanyak mungkin dengan kriteria yang diinginkan, sehingga memperoleh sesuai harga pasar.

Menurut Kotler \& Amstrong dalam [3] menyatakan bahwa Berbelanja online shop memiliki kelebihan yaitu, lebih efektif dan efisien, pembelian melalui online shop bisa dilakukan dimana saja dan kapan saja. Pembelian melalui online shop juga memiliki kelemahan yaitu, pembeli tidak bisa memegang produknya secara langsung, pembeli tidak dapat bertemu langsung dengan penjual. Ada juga beberapa kasus penipuan di online shop, dan tidak ada yang tahu mengenai jaminan barang sampai dengan aman dan tanpa kerusakan, kecuali ada garansi dari toko online shop. Namun banyak juga konsumen yang berbelanja di online shop.

Menurut Aziz dalam [4] mengemukakan "bahwa ANP pengelolaan kegiatan perhitungan matematika dalam penerapan dependence, feedback tersistem yang mengelola dan mengkombinasikan faktor-faktor tangible serta intangible [5] keputusan merupakan hal yang wajib di lalukan untuk mementukan sebuah keyakinan [4].

Pengunanya bukan saja dari kalangan orang dewasa generasi milenial, tapi berkembang dan dapat di gunakan juga di oleh anak-anak dan orang tua, sistem pememilihan barang yang mudah, transaksi yang dapat dilakukan dengan nontunai, hingga proses pengiriman barang yang sampai dengan cepat, disisi lain bagi para pedagang dimana sebelumnya harus meliliki ruko atau kios tempat usaha jika ingin berjualan namun sekarang tidak lagi membutuhkan hal tersebut yang tidak meliki tempat di sediakan oleh pengelola untuk mengelola barang dangganganya di aplikasi Marketplace, dan pembeli juga tidak usah dating lansung ke toko, namun bisa mengakses dengan mudah walau jarak tokonya jauh dari rumah.

Marketplace merupakan sebuah wadah untuk bertransaksi (antara pelaku usaha dan konsumen) yang dalam perbelanjaan online mulai menarik perhatian masyarakat. Khususnya di Indonesia sudah banyak contoh Marketplace yang kita kenal diantarannya adalah: Tokopedia, Lazada, JD.Id, Bukalapak, Shopee, dan masih banyak lagi yang lainnya. Dari semua Marketplace diatas mereka memiliki berbagai fasilitas yang berbeda namun fungsi mereka sama yaitu digunakan untuk memudahkan konsumen dalam bertransaksi. Dari penelitian ini penulis ingin menentukan Marketplace yang diminati oleh pengguna Marketplace berdasarkan Harga, Minat, dan Promosi. Dan Bagaimana cara memilih Marketplace dengan menggunakan metode ANP(Analytic Network Process). 


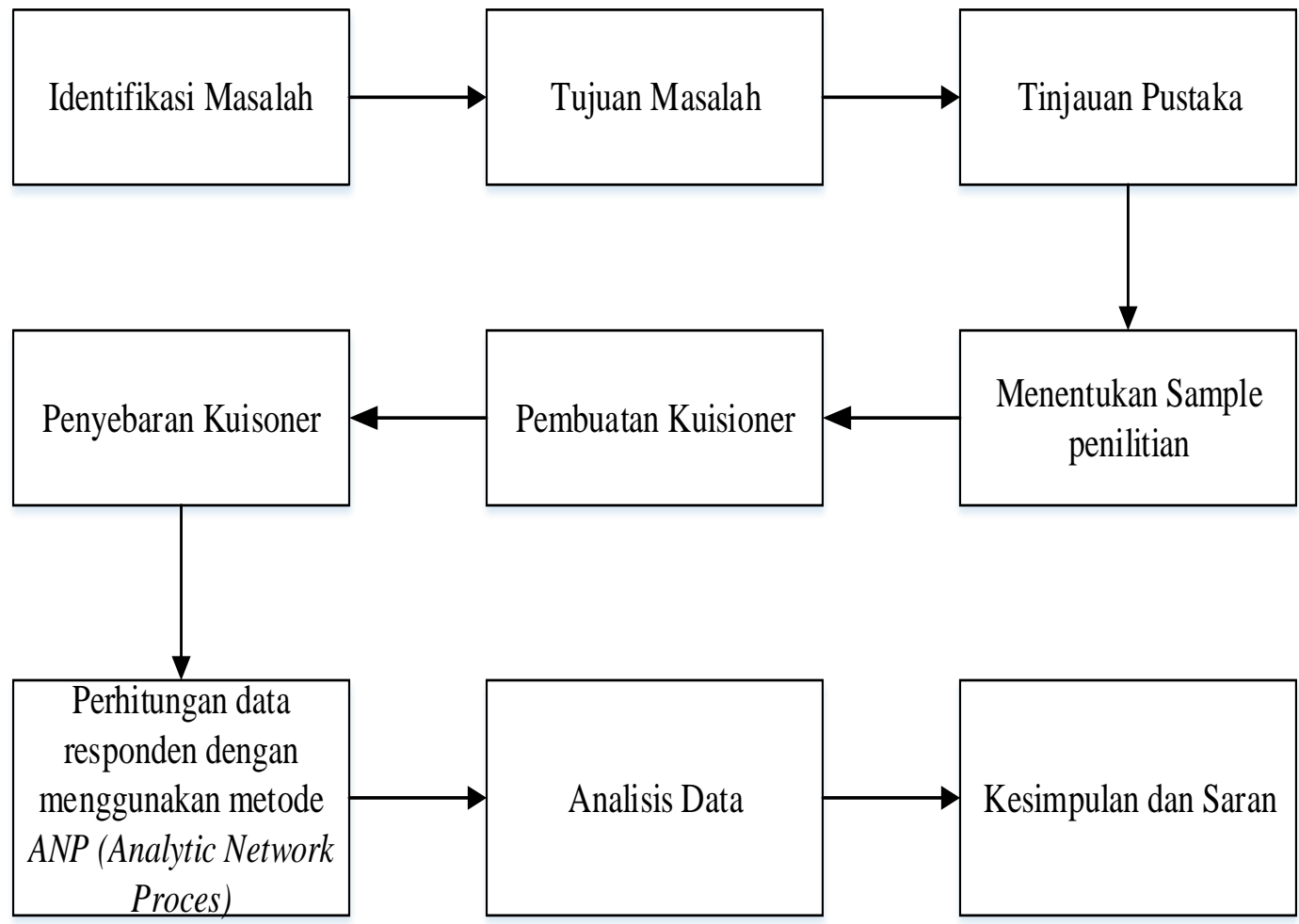

Sumber: Hasil Penelitian (2020)

Gambar 1. Alur penelitian

Proses pertama yang dilakukan penelitian ini adalah menentukan permasalahan yang ada diharapkan hasilnya tidak keluar dari proses tahapan penelitian, kedua pada langkah ini ditentukan tujuan Masalah dimana alur untuk mengetahui Selera masyarakat di fokuskan pada Pengguna aplikasi belanja dengan sistem online (Marketplace). Ditentukan Dari 5 aplikasi yang sudah di pilih, dengan dibuat 3 kategori yang sudah ditentukan dan dibahas di dalam penelitian ketiga mencari sumber referensi ditujukan untuk menyesuaikan teori- dari para ahli dan pakar pada bidangnya masing-masing dan dikolaborasikan dengan penelitian-penelitian yang pernah ada dan pernah dilakukan sebagai acuan untuk penelitian ini dan yang akan dijadikan landasan teori. Keempat pihak yang akan dfi mintakan pendapat (Responden) dari kalangan masyarakat umum pengguna Marketplace yang terdiri dari berbagai macam pekerjaan dan usia yang berkisar antara 15-25 tahun, kelima membuta pertayaan tentang berbandingan kriteria dan alterfatif pemilihan aplikasi belanja online, ke emam pengisian kuesioner, ketujuh teknik pengolahan, kedelapan analisis data di masukan agar data yang di dapat konsisten atau tidak. Dan sepuluh pengambilan kesimpulan.

\section{Metode Penelitian}

Penyebaran kuisioner dilakukan dengan memberikan kuisioner terhadap 30 responden yang telah ditentukan, dimana responden disini adalah penilai yang berhak menilai marketplace mana yang terpilih dari penentuan 3 (tiga kriteria yang telah ditetukan) Dalam metode ANP untuk pengelompokkan kriteria yang digunakan dikelompokkan dalam bentuk cluster dan 135lternfaktor yang saling berkaitan dan feedback.

Metode Penelitian menggunakan [6] ANP (Analytic Network Process) yang dikembangkan oleh Thomas L.Saaty dari metode hitung AHP (Analytical Hierarchy Process), dapat memecahkan masalah kompleks dimana aspek atau kriteria yang diambil cukup banyak.

Menurut [7] mengemukakan bahwa "Analytic Network Process (ANP) merupakan metode penilaian multi kriteria untuk strukturiasasi keputusan dan analisis yang memiliki kemampuan untuk mengukur konsistensi dari peniaian dan fleksibilitas pada pilihan dalam level Sub kriteria". 
Dekomposisi Menurut saaty (2003) dalam [8] Model hirarki keputusan adalah salah satu tujuan, kriteria yang dievaluasi berdasarkan relevansi mereka untuk tujuan dan 136lternative yang dievaluasi oleh bagaimana mereka lebih disukai untuk kriteria masing-masing. Tujuan, kriteria dan 136lternative semua elemen dalam masalah keputusan, atau node dalam model. Garis yang menghubungkan tujuan untuk masing-masing kriteria berarti bahwa kriteria harus dipasangkan dibandingkan dengan kepentingan mereka dalam kaitannya dengan tujuan. Demikian pula, garis yang menghubungkan masing-masing kriteria dengan cara alternative, alternative pasangan dibandingkan dengan kriteria yang diinginkan hal tersebut dapat dilihat pada gambar 2 dibawah ini.

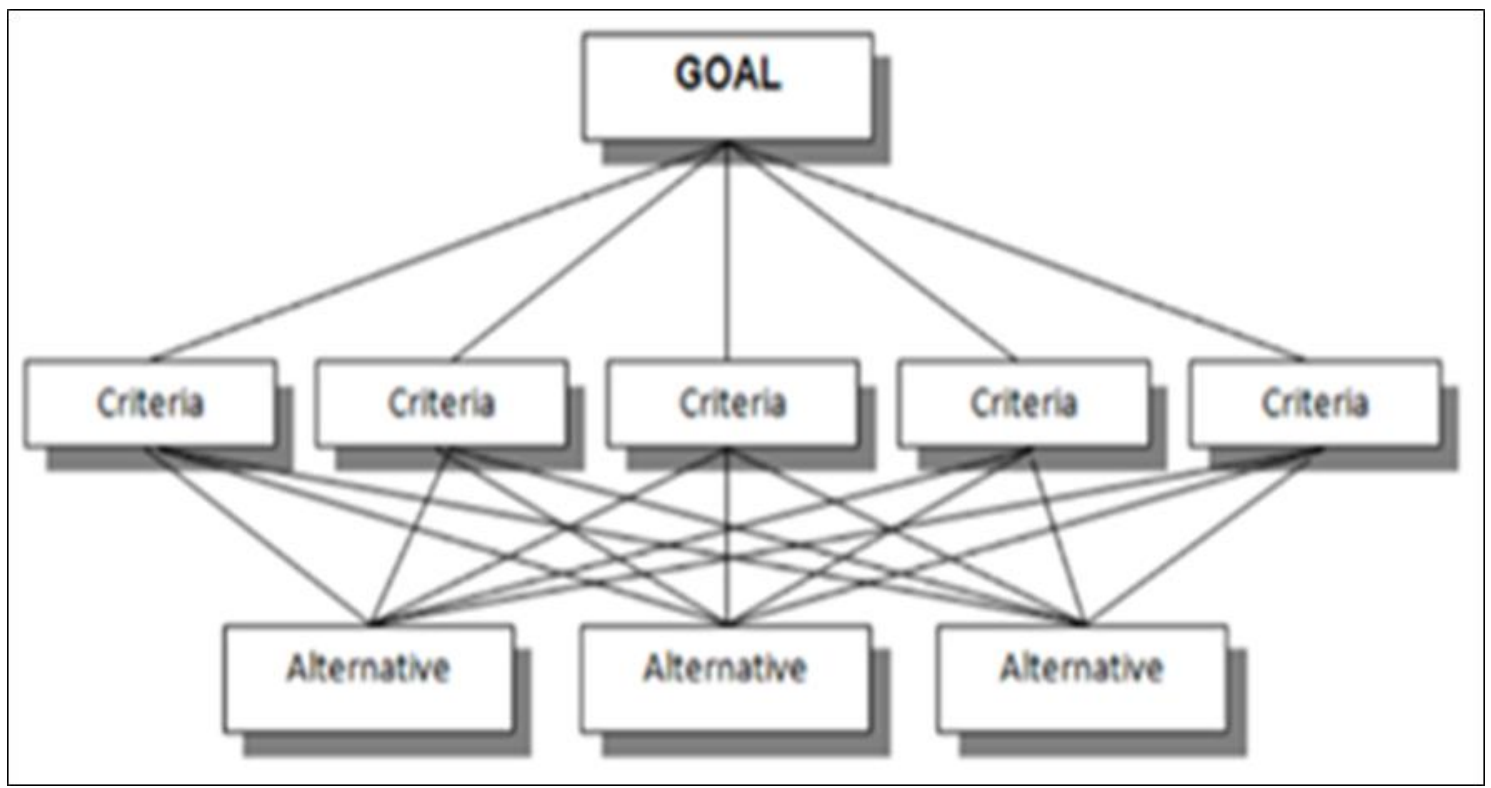

Sumber : W.Yusnaeni (2014)

Gambar 2. Abstract Representation of a Decision Hierarchy

Berbagai alternative yang ada yang pada kegiatan ini sudah ditemntukan terlebih dahulu, kemudian dari alternative tersebut dapat di jadikan beberapa kriteria untuk di jadikan model, sehingga dari kriteria tersebut bisa di ambil satu tujuan yang sesuai harapan.

Pendefinisian kegiatan ini akan dibangun perbandingan berpasangan berdasrkan semua komponen yang ada diharapkan hasilnya dijadikan skala kepentingan relatif dari komponen, penilaian berupa angka. "Perbandingan berpasangan dalam bentuk matrix jika dikombinasikan akan menghasilkan prioritas". Untuk itu Saaty (1986) menetapkan skala kuantitatif (1 sampai dengan 9) untuk menilai tingkat kepentingan suatu elemen terhadap elemn lainnya.

Tabel 1. Preferensi skala Saaty's 1-9 untuk AHP

\begin{tabular}{c|c}
\hline Tingkat Kepentingan & Definisi \\
\hline 1 & Sama penting \\
\hline 3 & Sedikit lebih penting \\
\hline 5 & Lebih penting \\
\hline 7 & Sangat penting \\
\hline 9 & Mutlak sangat penting \\
\hline $2,4,6,8$ & Nilai tengah \\
\hline
\end{tabular}

Sumber : Febriana S (2018)

\subsection{Prosedure Dasar ANP}

Menurut Nasution [9] menjelaskan secara umum prosedur yang harus dilakukan dalam menggunakan metode ANP adalah sebagai berikut :a. Mendefinisikan masalah dan menentukan kriteria solusi yang diinginkan, b. Menentukan prioritas elemen dengan membuat perbandingan pasangan dapat dilihat pada tabel 2 dibawah ini. 
Tabel 2. Pair Comparation Matrix Kriteria

\begin{tabular}{cccc} 
Kriteria & $\mathbf{1}$ & $\mathbf{2}$ & $\mathbf{3}$ \\
\hline $\mathbf{1}$ & 1,00 & & \\
\hline $\mathbf{2}$ & & 1,00 & 1,00 \\
\hline $\mathbf{3}$ & & & \\
\hline
\end{tabular}

Sumber : Febriana S (2018)

Matriks perbandingan berpasangan diisi dengan menggunakan bilangan untung merepresentasikan kepentingan relatif dari suatu elemen terhadap elemen yang lain. c. Melakukan pertimbangan-pertimbangan terhadap perbandingan berpasangan disintesis untuk memperoleh keseluruhan prioritas. Hal-hal yang dilakukan adalah: 1). Menjumlahkan nilai-nilai dari setiap kolom matriks, 2). Menentukan pembobotan komponen dari sudut pandang manajerial, 3). Membuat matriks perbandingan berpasangan yang menggambarkan kontribusi atau penaruh dari setiap elemen atas setiap kriteria, 4). Mengumpulkan semua data perbandingan berpasangan dan memasukan nilai-nilai kebalikannya serta nilai satu disepanjang diagonal utama, prioritas masing-masing kriteria dicari dan konsistensi diuji, 5). Menentukan eigenvector dari matriks yang telah dibuat pada langkah ketiga, 6). Membuat unweighted super matrix dengan cara memasukkan semua eigen vector yang telah dihitung pada langkah 5 kedalam sebuah super matriks, 7). Membuat weighted super matrix dengan cara melakukan perkalian setiap isi unweighted supermatrix terhadap matriks perbandingan kriteria, 8). melakukan limiting supermatriks menggubakan prosedur pemangkatan super matriks secara berkelanjutan, hingga di dapat angka disetiap kolom dalam satu barisdengan hasil sama besar, dan melakukan proses normalisasi terhadap limiting supermatriks, 9). Hitung Consistency Index (Cl) dan Hitung Rasio Konsistensi dengan persamaan dibawah ini :

$C I=\left(\frac{\wedge \max -n}{n-1}\right)$.

$\mathrm{Cl}=$ Consistency Index (Rasio penyimpangan konsistensi)

$\wedge$ max $=$ Nilai eigen terbesar dari matriks berordo $n$

$\mathrm{n} \quad=$ Banyaknya elemen

$C R=\frac{C I}{I R}$

$\mathrm{CR}=$ Consistency Ratio

$\mathrm{Cl}=$ Consistency Index

$\mathrm{IR}=$ Indeks Random

Kemudiah tahap terakhir adalah memeriksa konsitensi hierarki. Bila terdapat nilainya lebih dari $10 \%$, harus dilakukan perbaikan data, sebaliknya jika rasio konsitensi $(\mathrm{Cl} / \mathrm{CR})$ kurang atau sama dengan 0,1, maka di mungkinkan hasil perhitungan bisa dinyatakan benar. Dimana IR indeks random yang nilainya dapat dilihat pada tabel 3 dibawah ini .

Tabel 3. Daftar Indeks Random Konsitensi

\begin{tabular}{c|c}
\hline N (Jumlah Kriteria & IR \\
\hline 1 & 0 \\
\hline 2 & 0 \\
\hline 3 & 0,58 \\
\hline 4 & 0,90 \\
\hline 5 & 1,12 \\
\hline 6 & 1,24 \\
\hline 7 & 1,32 \\
\hline 8 & 1,41 \\
\hline 9 & 1,45 \\
\hline 10 & 1,49 \\
\hline 11 & 1,51 \\
\hline 12 & 1,48 \\
\hline 13 & 1,56 \\
\hline 14 & 1,57 \\
\hline
\end{tabular}




\begin{tabular}{c|c}
\hline $\mathrm{N}$ (Jumlah Kriteria & $\mathrm{IR}$ \\
\hline 15 & 1,59 \\
\hline Sumber: Hasil Penelitian (2020)
\end{tabular}

\section{Hasil dan Pembahasan}

Adapun proses pengolahan data, dan analisa data yang dilakukan oleh penulis didahului dengan menetukan elemen-elemen yang signifikan terhadap masing-masing kriteria dan alternatifnya. Untuk Mengetahui Marketplace mana yang paling banyak medominasi untuk diminati oleh masyarakat penggunanya dalam pemilihan Marketplace terbaik Dimulai dari : 1). Penentuan tujuan utama “Aplikasi Belanja Online (Marketplace) Yang Dipilih". 2). Kriteria-kriteria "Harga, Minat, dan Promo". 3). Alternatif "Shopee, Lazada, Tokopedia, Bukalapak, Blibli.com."Setelah semua elemen-elemen telah ditentukan maka selanjutnya akan dilakukan kajian dengan menggunakan metode ANP (Analytic Network Proces) untuk menjawab rumusan masalah sesuai dengan yang diajukan berdasarkan proses hirarki analitis. Observasi dilakukan agar teknik pengumpulan data sesuyai harapan, proses kajian dengan pengamatan secara langsung ke sumber objek penelitian untuk melihat dari dekat kegiatan yang dilakukan, penggunaan Google Form memudahkan masyarakat umum pengguna Marketplace untuk menjawab pertanyaan dan kita jadikan sebagai data primer,

\subsection{Pembobotan Hirarki untuk Semua Kriteria}

Hasil analisis menunjukkan bahwa kriteria harga 3 kali lebih penting dibandingkan dengan kriteria promo, sedangkan kriteria minat 5 kali lebih penting dibandingkan dengan kriteria promo, dan kriteria minat 4 kali lebih penting dari pada kriteria harga. Maka dari itu langkah - langkah perhitungan matrik perbandingan hasil referensi diatas sebagai berikut: 1). Kriteria yang akan menjadi penentu yaitu Harga, Minat, dan Promo. 2). Menyusun kriteria-kriteria pemilihan aplikasi belanja online Marketplace dengan matrix berpasangan. Susun angka awal untuk menentukan nilai kriteria. 3). Menjumlahkan nilai elemen dari setiap kolom dari nilai-nilai yang telah di tentukan diatas, maka keterangan jumlah nilai pada elemen setiap kolom adalah:

Harga $: 1.00+0.33+4.00=5.33$.

Promo : $: 3.00+1.00+5.00=9.00$.

Minat $: 0.25+0.20+1.00=1.45$.

Membagi setiap elemen pada kolom dengan jumlah perkolom sesuai dari nilai-nilai elemen matriks pada table matrisk yang disederhanakan. Dan jumlah masing-masing kolom diatas,maka dapat dihitung matriks normalisasinya dengan cara membagi setiap elemen pada kolom yang di sesuaikan dengan jumlah kolom. 5). Dari perhitungan normalisasi diatas didapatkan, selanjutnya dapat dijumlahkan perbaris untuk mendapatkan hasil dari masing masing baris dengan perhitungan sebagai berikut: 6). Priority Vector (Bobot Kriteria) dari setiap baris. 7). Menguji konsistensi dapat dilakukan dengan cara mengalikan matriks perbandingan berpasangan awal dengan hasil dari priority vector (bobot kriteria) lalu dapat dihitung hasil pembagian antara hasil kali dengan priority vector (bobot kriteria). Hasil kali didapatkan dari hasil perkalian matriks baris dengan kolom, dengan penjabaran sebagai berikut:

Harga $:(1.00 * 0.23)+(3.00 * 0.10)+(0.25 * 0.67)=0.71$

Promo : $(0.33 * 0.23)+(1.00 * 0.10)+(0.20 * 0.67)=0.31$

Minat $:(4.00 * 0.23)+(5.00 * 0.10)+(0.20 * 0.67)=2.11$

Setelah hasil perkalian matriks awal dengan priority vector (bobot kriteria) dan didapatkan hasil kali maka hasil dapat di bagi dengan priority vector (bobot kriteria) untuk mendapatkan hasil bagi. Hasil bagi didapatkan dari hasil pembagian hasil kali dengan priority vector (bobot kriteria) dengan penjabaran sebagai berikut: Harga: $0.71 / 0.23=3.07$, Promo: $0.31 / 0.10=3.02$, Minat: $2.11 / 0.67=3.17 .8$ ). Menghitung $\lambda$ max dengan menggunakan rumus : Jumlah hasil bagi $/ \mathrm{N}$. Dengan penjabaran sebagai berikut: $(3.07+3.02+3.17) / 3=3.09$. 9). Hitung Consistency Index $\mathrm{Cl}=(\lambda \max -\mathrm{n}) /(\mathrm{n}-1) \mathrm{Cl}=(3.09-3) /(3-1)=0.04$. 10). Hitung Rasio Konsistensi dengan persamaan dibawah ini : $\mathrm{CR}=\mathrm{CI} / \mathrm{IR}$. IR adalah Indeks random dengan ketentuan nilai pembagi yaitu 0.58 karena pada kasus ini peneliti memiliki ukuran matriks 3. Sehingga CR dapat di hitung sebagai berikut : $\mathrm{CR}=0.04 / 0.58=0.07(7 \%)$. 
Dapat disimpulkan dari perhitungan ANP berdasarkan keseluruhan kriteria rasio konsistensi memiliki jumlah $\leq 0.1(10 \%)$ dan hasilnya $0.07(7 \%)$ maka matriks tersebut dapat dikatakan konsisten.

\subsection{Alternatif berdasarkan kriteria Harga}

Harga merupakan suatu unnsur yang dicari oleh konsumen dalam menentukan pembelian suatu produk yang di minati konsumen, Menguji konsitensi dapat dilakukan dengan cara mengalikan matriks perbandingan berpasangan awal dengan hasil dari priority vector (bobot kriteria) lalu dapat dihitung hasil pembagian antara hasil kali dengan priority vector (bobot kriteria).1). Hasil kali didapatkan dari hasil perkalian matriks baris dengan kolom, dengan penjabaran sebagai berikut:

$\begin{array}{ll}\text { Shopee } & :\left(1.00^{*} 0.21\right)+\left(3.00^{*} 0.12\right)+\left(1.00^{*} 0.21\right)+(0.33 * 0.38)+(3.00 * 0.08)=\mathbf{1 . 1 3} \\ \text { Lazada } & :\left(0.33^{*} 0.21\right)+\left(1.00^{*} 0.12\right)+\left(0.33^{*} 0.21\right)+\left(0.50^{*} 0.38\right)+\left(2.00^{*} 0.08\right)=\mathbf{0 . 6 0} \\ \text { Tokopedia } & :\left(1.00^{*} 0.21\right)+\left(3.00^{*} 0.12\right)+\left(1.00^{*} 0.21\right)+\left(0.33^{*} 0.38\right)+\left(3.00^{*} 0.08\right)=\mathbf{1 . 1 3} \\ \text { Bukalapak } & :\left(3.00^{*} 0.21\right)+\left(2.00^{*} 0.12\right)+\left(3.00^{*} 0.21\right)+(1.00 * 0.38)+\left(3.00^{*} 0.08\right)=\mathbf{2 . 1 1} \\ \text { Blibli.com } & :\left(0.33^{*} 0.21\right)+\left(0.50^{*} 0.12\right)+\left(0.33^{*} 0.21\right)+\left(0.33^{*} 0.38\right)+(3.00 * 0.08)=\mathbf{0 . 4 0}\end{array}$

Setelah hasil perkalian matriks awal dengan priority vector (bobot kriteria) dan didapatkan hasil kali maka hasil dapat di bagi dengan priority vector (bobot kriteria) untuk mendapatkan hasil bagi. Hasil bagi didapatkan dari hasil pembagian hasil kali dengan priority vector (bobot kriteria) dengan penjabaran sebagai berikut :

$\begin{array}{ll}\text { Shopee } & : 1.13 / 0.21=5.39 \\ \text { Lazada } & : 0.60 / 0.12=5.13 \\ \text { Tokopedia } & : 1.13 / 0.21=5.39 \\ \text { Bukalapak } & : 2.11 / 0.38=5.51 \\ \text { Blibli.com } & : 0.40 / 0.08=5.23\end{array}$

Menghitung $\lambda$ max dengan menggunakan rumus : Jumlah hasil bagi / $\mathrm{N}$. Dengan penjabaran sebagai berikut: $(5.39+5.13+5.39+5.51+5.23) / 5=5.33$. Hitung Consistency Index $(\mathrm{Cl})$ dengan persamaan dibawah ini: $\mathrm{Cl}=(5.33-5) /(5-1)=0.08$. 3). Hitung Rasio Konsistensi dengan persamaan dibawah ini: $\mathrm{CR}=\mathrm{Cl} / \mathrm{IR}$. IR adalah Indeks random dengan ketentuan nilai pembagi yaitu 1.12 karena pada kasus ini peneliti memiliki ukuran matriks 5 . Sehingga $C R$ dapat di hitung sebagai berikut: $C R=0.08 / 1.12=0.07(7 \%)$.

Dapat disimpulkan dari perhitungan ANP berdasarkan keseluruhan alternatif berdasarkan kriteria harga rasio konsistensi memiliki jumlah $\leq 0.1(10 \%)$ dan hasilnya $0.07(7 \%)$ maka matriks tersebut dapat dikatakan konsisten.

\subsection{Kriteria Minat}

Mengalikan matriks perbandingan berpasangan awal dengan hasil dari priority vector (bobot kriteria) lalu dapat dihitung hasil pembagian antara hasil kali dengan priority vector (bobot kriteria).Menghitung $\lambda$ max dengan menggunakan rumus : Jumlah hasil bagi / $\mathrm{N}$.

Dengan penjabaran sebagai berikut: $(5.53+5.29+5.32+5.51+5.50) / 5=5.43$.

Hitung Consistency Index $(\mathrm{Cl})$ dengan persamaan dibawah ini: $\mathrm{Cl}=(5.43-5) /(5-1)=0.11$. Hitung Rasio Konsistensi dengan persamaan dibawah ini: $\mathrm{CR}=\mathrm{Cl} / \mathrm{IR}$. IR adalah Indeks random dengan ketentuan nilai pembagi yaitu 1.12 karena pada kasus ini peneliti memiliki ukuran matriks 5. Sehingga CR dapat di hitung sebagai berikut: $C R=0.11 / 1.12=0.10(10 \%)$.

Dapat disimpulkan dari perhitungan ANP berdasarkan keseluruhan alternatif berdasarkan kriteria minat rasio konsistensi memiliki jumlah $\leq 0.1(10 \%)$ dan hasilnya $0.10(10 \%)$ maka matriks tersebut dapat dikatakan konsisten.

\subsection{Kriteria Promo}

Adapun untuk melakukan perhitungan kriteria promo dimulai dari: 1). Menghitung $\lambda$ max dengan menggunakan rumus: Jumlah hasil bagi / N. Dengan penjabaran sebagai berikut: $(5.42+5.42+5.31+5.38+5.30) / 5=5.37 .2)$. Hitung Consistency Index $(\mathrm{Cl})$ dengan persamaan dibawah ini: $\mathrm{Cl}=(5.37-5) /(5-1)=0.09$. 3). Hitung Rasio Konsistensi dengan persamaan dibawah ini: $\mathrm{CR}=\mathrm{Cl} / \mathrm{IR}$. IR adalah Indeks random dengan ketentuan nilai pembagi yaitu 1.12 
karena pada kasus ini peneliti memiliki ukuran matriks 5 . Sehingga CR dapat di hitung sebagai berikut: $\mathrm{CR}=0.09 / 1.12=0.08(8 \%)$.

Dapat disimpulkan dari perhitungan ANP berdasarkan keseluruhan alternatif berdasarkan kriteria promo rasio konsistensi memiliki jumlah $\leq 0.1(10 \%)$ dan hasilnya $0.08(8 \%)$ maka matriks tersebut dapat dikatakan konsisten.

\subsection{Kriteria Minat}

Pengolahan data menggunakan Software Super Decision versi Windows 7 perbandingan berpasangan terhadap semua alternatif berdasarkan kriteria minat yaitu nilai Consistency Ratio adalah 0.09 , sedang pengolahan data secara manual menggunakan metode ANP menghasilkan nilai yaitu 0.10 , penjelasannya dapat dilihat pada gambar 3 dibawah ini.

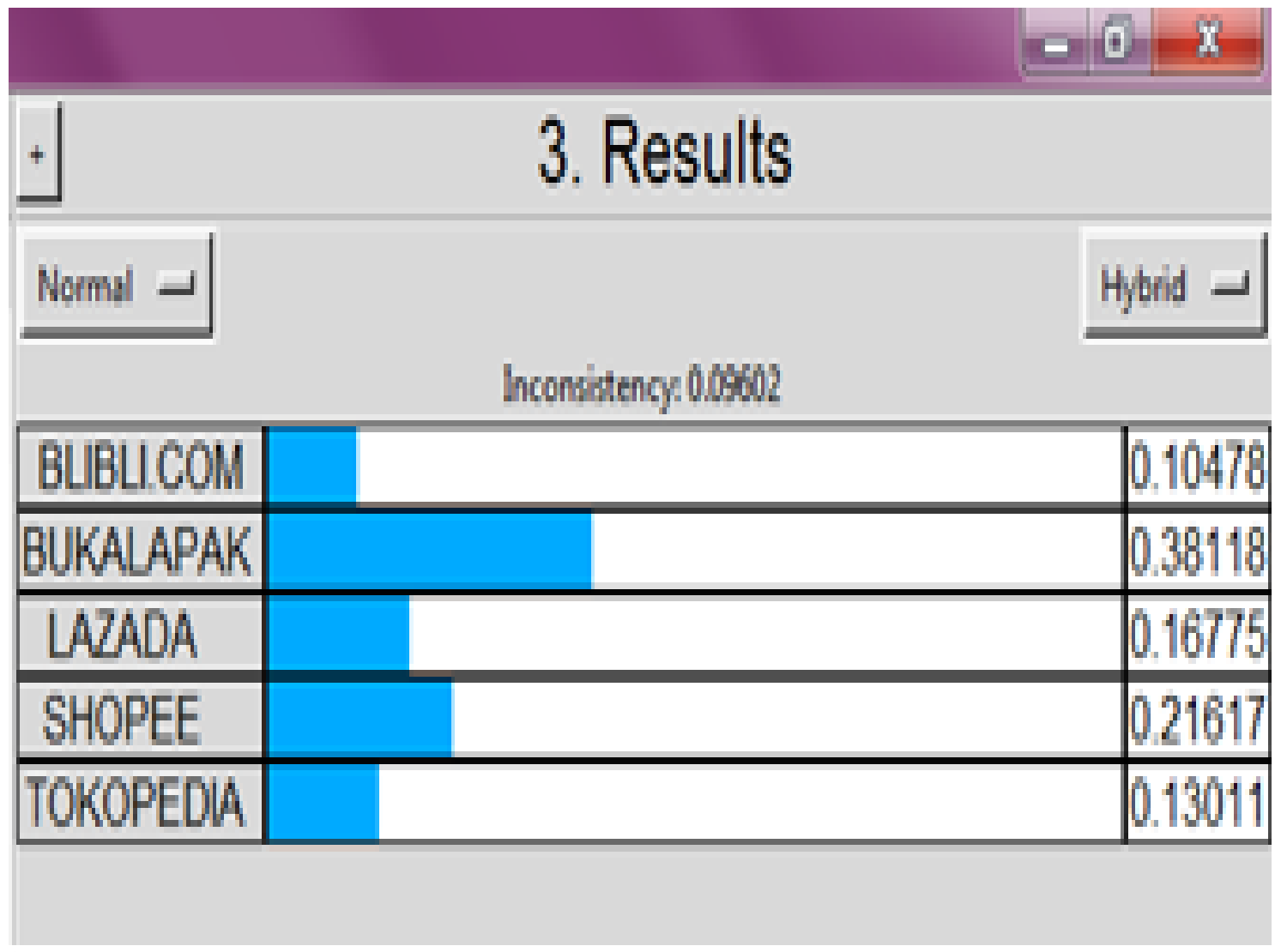

Sumber: Hasil Penelitian (2020)

Gambar 3. Result Minat

Dari perbandingan hasil akhir pengolahan data tersebut berbeda dengan hasil pembulatan secara manual dan tidak merubah urutan prioritas Bukalapak diurutan pertama, menyusul dengan Shopee, Lazada, Tokopedia, Blibli.com.

\subsection{Kriteria Promo}

Nilai Consistency Ratio adalah 0.09 , sedang pengolahan data secara manual menggunakan metode ANP menghasilkan nilai yaitu 0.08. Dari perbandingan hasil akhir pengolahan data tersebut berbeda dengan hasil pembulatan secara manual dan tidak merubah urutan prioritas Shopee diurutan pertama yang lebih mendominasi paling banyak diminati customernya, menyusul di tahapan beikutnya dengan Tokopedia, Bukalapak, Lazada, Blibli.com hasil dapat dilihat pada gambar 4 berikut ini. 


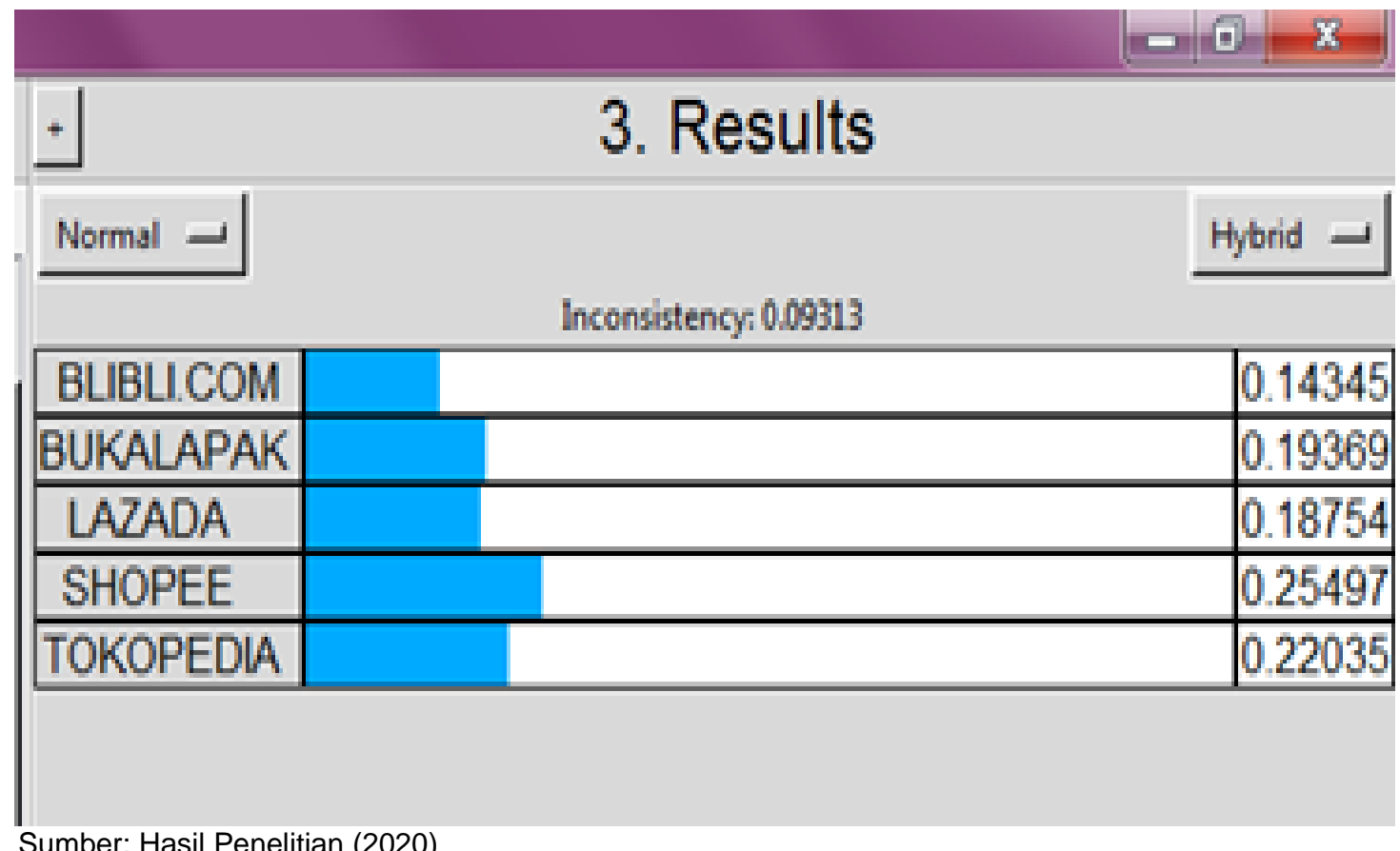

Gambar 4. Result Promo

\subsection{Kriteria Harga}

Perbandingan berpasangan terhadap semua alternatif berdasarkan kriteria harga yaitu nilai Consistency Ratio adalah 0.07 , sedang pengolahan data secara manual menggunakan metode ANP menghasilkan nilai yaitu 0.07. Dari perbandingan hasil akhir pengolahan data tersebut sama dan tidak merubah urutan prioritas Bukalapak diurutan pertama, menyusul Shopee, Tokopedia, Lazada, Blibli.com hasil dapat dilihat pada gambar 5 berikut ini.

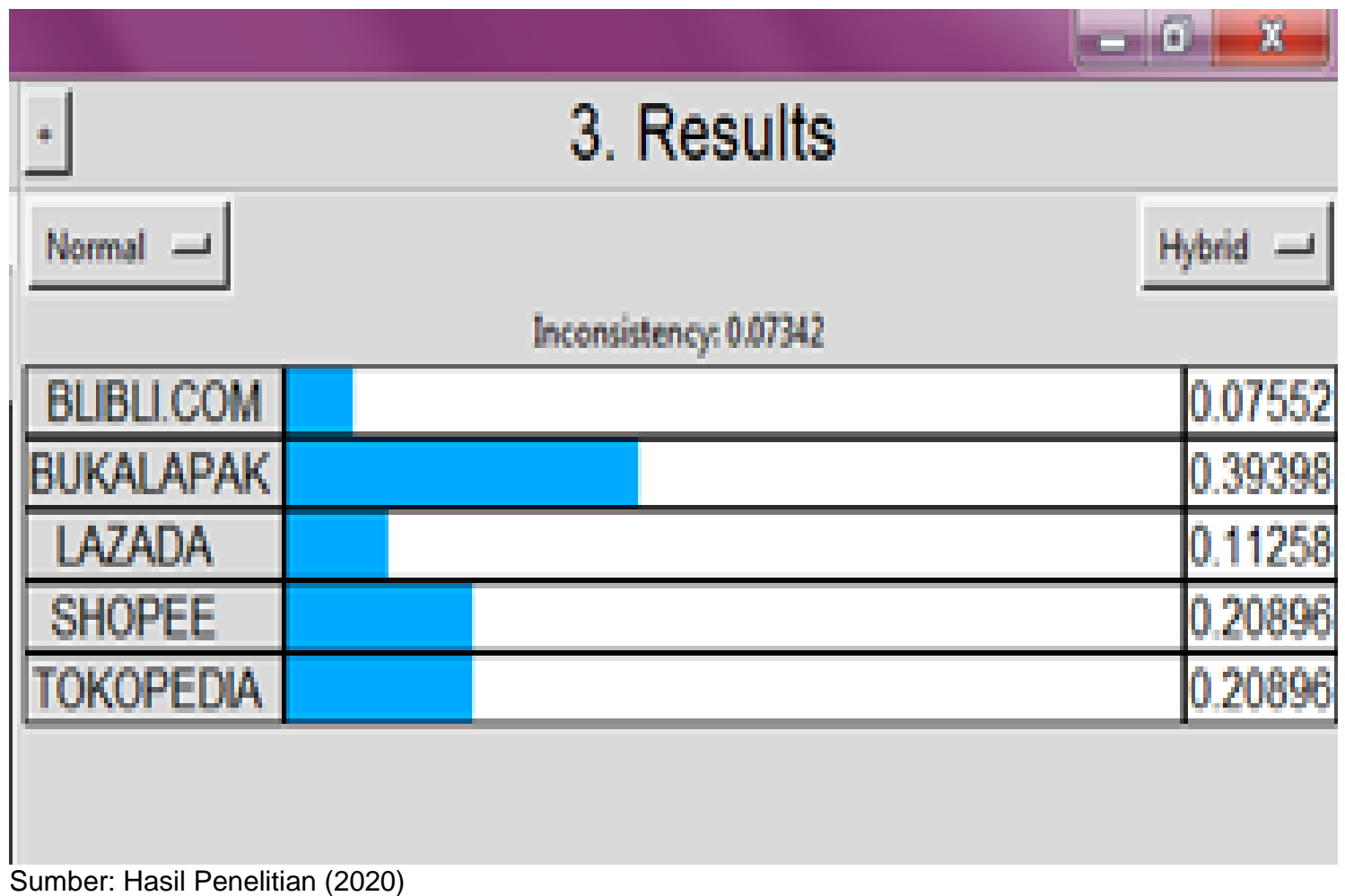

Sumber: Hasil Penelitian (2020)

Gambar 5. Result Harga 


\subsection{Semua Alternatif}

Semua laternatif dimaksudkan sebagai pembanding darei 5 kreteria yang sudah di ajukan, dari semua alternatif Didapat bahwa Aplikasi Bukalapak menjadi alternative pilihan nomor 1 (satu) dalam pemilihan aplikasi belanja online marketplace dari 5 alternatif yng di sajikan, di susul pada urutan kedua yaitu Shopee dan urutan selanjutnya yaitu Lazada, Tokopedia dan urutan terakhir yaitu Blibli.com hasil dapat dilihat pada tabel 4 berikut ini:

Tabel 4. Hasil Semua Alternatif

\begin{tabular}{lcrcc}
\multicolumn{1}{c}{ Name } & Graphic & Ideals & Normals & Raw \\
\hline BLIBLI.COM & & 0.279508 & 0.102075 & 0.051038 \\
\hline BUKALAPAK & & 1.000000 & 0.365196 & 0.182598 \\
\hline LAZADA & & 0.430717 & 0.157296 & 0.078648 \\
\hline SHOPEE & & 0.598177 & 0.218452 & 0.109226 \\
\hline TOKOPEDIA & & 0.429852 & 0.156980 & 0.078490 \\
\hline
\end{tabular}

Sumber: Hasil Penelitian (2020)

\section{Kesimpulan}

Berdasarkan dari beberapa pengujian-pengujian yang dilakukan terhadap hipotesis dan masalah yang ada, maka dapat disimpulkan sebagai berikut : a). Metode ANP digunakan untuk Sistem Pendukung Keputusan Khususnya dalam kasus Seperti ini dengan kriteri, setelah perhitungan dengan ANP diperoleh prioritas kriteria yang paling diprioritaskan dengan bobot nilai tertinggi. Dengan nilai konsisten $<0.1$. dari hasil perhitngan diatas yang memegang kedudukan pertama dalam pembobotan kriteria ya itu minat. Secara tidak langsung masyarakat menggunakan minat mereka untuk memulai berbelanja di suatu marketplace. b). Penerapan metode hitung ANP didapat Bukalapak menjadi prioritas sebagai pilihan nomor 1 (satu) dalam kategori aplikasi belanja online. Dilajutkan dengan shopee, tokopedia lazada dan blibli.com, c). Perbandingan dari kriteria harga bukalapak menjadi priorotas utama menyusul shopee, tokopedia, lazada, blibli.com

\section{Referensi}

[1] Rahman TADPF, Mandala EPW, "Perancangan Aplikasi Sistem Pakar Dengan Menggunakan Metode Certainty Factor Untuk Menentukan Jenis Gangguan Disleksia Berbasis Web," Inkofar, vol. 1, no. 1, pp. 12-17, 2017.

[2] D. Apriadi, A. Y. Saputra, "E-Commerce Berbasis Marketplace Dalam Upaya Mempersingkat Distribusi Penjualan Hasil Pertanian," vol. 1, no. 12, pp. 1684-1689, 2017.

[3] Rahmawaty, "Pengaruh harga dan minat beli terhadap keputusan pembelian konsumen Shopee," vol. 2, pp. 1-8, 2018.

[4] P. T. Pungkasanti, "Penerapan Analytic Network Process ( Anp )," vol. 14, pp. 66-71, 2017.

[5] S. F. C. H. Maryuliana, Imam Much Ibnu Subroto, "Sistem Informasi Angket Pengukuran Skala Kebutuhan Materi Pembelajaran Tambahan Sebagai Pendukung Pengambilan Keputusan Di Sekolah Menengah Atas Menggunakan Skala Likert," TRANSISTOR Elektro dan Inform. (transistor El), vol. 1, no. oktober, pp. 1-12, 2016.

[6] H. Pratiwi, Buku Ajar Sistem Pendukung Keputusan. 2016.

[7] B. Sinaga and P. S. Hasugian, "Pemilihan Media Promosi STMIK Pelita Nusantara Medan dengan Metode Analytic Network Process ( ANP )," vol. 4, no. 1, pp. 5-9, 2019.

[8] W. Yusnaeni, "Strategi Pemberian Bonus Karyawan Pabrik Kaca Untuk Mengingkatkan Kinerja Karyawan Dengan Metode Analytic Network Process (ANP)," vol. 2, pp. 561-565, 2014.

[9] A. B. Nasution, "Penerapan Sistem Pendukung Keputusan Dalam Memilih Rumah Sakit Bersalin Dengan Metode ANP," vol. 2, no. 1, pp. 73-83, 2018.

[10] F. Sari, Metode Dalam Pengambilan Keputusan. Yogyakarta: Deepublisher, 2018. 